\title{
O CINEMA NOVO E O GOVERNO DE JANGO: OS CPC'S DA UNE E A PROPAGAÇÃO DA ARTE CINEMATOGRÁFICA BRASILEIRA
}

\author{
Onesino Elias Miranda Neto ${ }^{1}$ \\ Hamilcar Silveira Dantas Júnior ${ }^{2}$
}

RESUMO: Neste trabalho a articulação entre os acontecimentos do Brasil ao longo do governo de João Goulart e as ações do Centro Popular de Cultura (CPC) da União Nacional dos Estudantes (UNE) possibilitou o fortalecimento e fomento do Cinema Novo no país. Em um período político de grandes agitações sociais, a arte e a cultura não ficariam isentas desta efervescência tão característica deste momento em especial. Sendo assim, diversas obras estavam intimamente ligadas à busca pela identidade nacional.

Palavras-chave: João Goulart. CPC. UNE e Cinema Novo.

\section{INTRODUÇÃO}

O governo de João Goulart (196I-1964) foi um dos mais conflituosos da história do Brasil ao longo do período republicano, já sendo iniciado pós uma renúncia presidencial e com diversos percalços através dos mecanismos utilizados por seus adversários, que vão, desde sua pecha de ter sido ministro do trabalho do governo de Getúlio Vargas, carregando assim a alcunha de populista, até uma tentativa de seus opositores de impedirem o seu exercício no Poder Executivo, tendo assim um plebiscito para a escolha do modelo administrativo no país (parlamentarismo x presidencialismo), graças à campanha de seu cunhado Leonel Brizola, Jango (como era conhecido o presidente) manteve-se na estrutura presidencialista, porém, não por muito tempo, devido ao golpe militar de 1964, interrompendo a democracia construída durante a Terceira República, sendo um

\footnotetext{
Aluno do PPGCINE - Programa de Pós-Graduação Interdisciplinar em Cinema da UFS Universidade Federal de Sergipe. onesino@hotmail.com

${ }^{2}$ Professor doutor do Depto. Educação Física e do Programa de Pós-graduação Interdisciplinar em Cinema (PPGCINE/UFS). hamilcarjr@hotmail.com
} 
período de grandes embates entre as classes populares e a classe média ligada à burguesia brasileira.

Em suas tentativas de levar o governo brasileiro a trilhar um caminho nacional-reformista, João Goulart procurou um apoio mais abrangente do que $\mathrm{o}$ das forças populares em geral. $O$ posicionamento nacionalreformista foi também favorecido pela pequena e média burguesia industrial local que visava a atingir mercados de baixo poder aquisitivo, bem como pelo setor agrário que produzia gêneros alimentícios para o mercado interno. Esses setores tentavam por intermédio de um apelo nacionalista e reformista junto à massa, alargar suas bases sociais por razões econômicas próprias. Eles sentiam a pressão do caráter concentracionista do processo de expansão capitalista no Brasil, o que estimulava a deteriorização dos salários reais das classes trabalhadoras urbanas. Por outro lado, o consumo de bens duráveis produzidos pelos novos setores industriais (automóveis, aparelhos eletrodomésticos), era assegurado por esse mesmo caráter concentracionista da economia, assim como pela formação muito difundida das novas ocupações tipicamente classes médias que serviam à nova estrutura de produção, ou seja, à burguesia tecnoprofissional. (DREIFUSS, I98I, p.130-I3I).

Este artigo/ensaio trabalha as relações sociais entre o governo de João Goulart e o Cinema Novo, entende-se que neste período as políticas trabalhistas, de reformas de base e de diálogos com diversos setores sociais atrelando-se, assim, aos movimentos sociais e estudantis, possibilitaram o fomento das obras fílmicas através da criação dos Centros Populares de Cultura da UNE - União Nacional dos Estudantes. Em uma primeira perspectiva entende-se aqui que a dinâmica governamental do presidente João Goulart e a conciliação de classes promovida pelos projetos nacionalistas do PTB e esquerdista do PCB permitiram que novos olhares sobre a questão da identidade nacional nas artes, em especial no Cinema, entrassem em ebulição.

Têm-se como cerne principal neste trabalho entender como o Cinema Novo conseguiu se difundir durante o governo João Goulart, sendo assim, compreender o papel dos CPC's da UNE nesse processo, além de identificar as principais características do governo Jango e do golpe de 1964.

Para desenrolar este pequeno esboço fez-se necessário o diálogo com alguns autores que mergulharam nos estudos acerca da história política brasileira, em especial, o período que antecede o golpe de 1964, tais como Caio Navarro de Toledo na compreensão das diretrizes sociais e políticas do país governado por João Goulart, 
Marcos Napolitano e Roberto Schwarcz, tendo em vista um diálogo literário relacionado à cultura e política e por fim, Fernando Mascarello e Jean-Claude Bernardet no descortinamento histórico da trajetória do Cinema Novo. Não obstante, outros autores serão de grande valia na construção deste artigo.

No intuito de organizar a perspectiva do texto e atingir os objetivos destinados com maior clareza o trabalho será fragmentado em um capítulo relacionado ao governo Jango e a política da Terceira República, um segundo capítulo um breve histórico dos CPC's e um terceiro capítulo sobre o contexto do Cinema Novo ao longo do governo aqui supracitado.

A construção administrativa do período relacionado ao governo de João Goulart está pautada nas ideias de Reformas de Base, além das intensas manifestações sociais que visavam conquistas dos setores dos trabalhadores, as Ligas Camponesas, os movimentos sindicais, os estudantes da UNE, as revoltas das baixas patentes das forças armadas, dentre outras, desagradavam os setores conservadores da sociedade brasileira, é por este cerne que este pequeno trabalho concentra-se no primeiro capítulo.

A crise do populismo originou-se e desdobrou-se no âmago do conflito de classe e da luta de classe, afetando a integração da sociedade e desafiando a autoridade das classes dominantes em seu conjunto. A incapacidade do regime populista de impor sua direção ideológica (ético-política) era, em última instância, a incapacidade da aliança no poder de superar por si mesma suas próprias contradições exacerbadas. Chegou-se a uma conjuntura histórica onde um conflito trágico tornou-se um conflito diádico. Este conflito triádico compunha-se de: I) um bloco histórico populista versus um bloco de poder multinacional e associado emergente; 2) um bloco histórico populista versus classes subordinadas e um bloco popular-trabalhista; 3) um bloco de poder multinacional-associado versus classes subordinadas." (DREIFUSS, 1981, p. 144-145)

Os Centros Populares de Cultura expressavam a riqueza de um período de grandes produções nas linguagens musicais, teatrais e cinematográficas que se disseminavam pelo território nacional, destacando-se o Teatro de Arena e o Cinema Novo, as experiências do UNE Volante propiciavam a difusão destas manifestações artísticas, sendo o contexto a ser abordado por este artigo no capítulo posterior.

A continuada expansão do CPC da UNE logo mobilizou um bom número de intelectuais, que the foram dar o apoio concreto de suas capacidades. Poetas como Ferreira Goullar (cuja mulher, a animadora cultural Teresa 
Aragão, teve relevantes funções na promoção do movimento), cineastas como Leon Hirszman, Alex Viany e Cacá Diégues, teatrólogos, escritores, pintores, jornalistas, músicos se foram juntando a ele, com maior ou menor dedicação de tempo e trabalho, sendo impossível arrolar aqui tão longa e brilhante nominata." (BARCELLOS, 1994, p.II)

Os filmes produzidos entre 1950 e 1964 entravam em um contexto de uma nação jovem, que buscava sua industrialização, urbanizada, porém com graves problemas sociais, assim é que o Cinema Novo surge, contando com o fortalecimento dos CPC's as obras cinematográficas de Nelson Pereira dos Santos, Glauber Rocha, dentre outros contribuíram para a formação da identidade cultural brasileira, no último capítulo deste texto visa-se entender como o Cinema Novo desenvolveu-se ao longo do governo Jango.

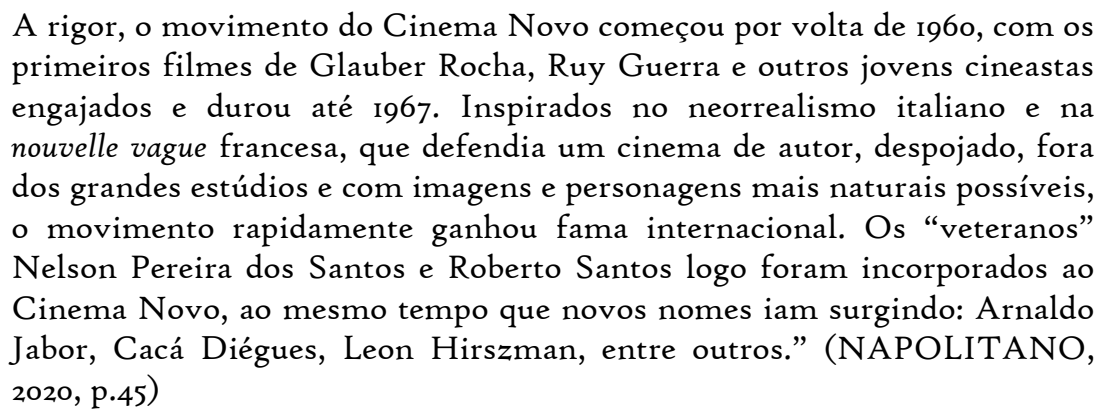

Faz-se mister que neste ensaio a meta será de contribuir com reflexões acerca desse movimento que, em meio a uma efervescência cultural, buscou ser uma resistência de construção da identidade nacional.

\section{O GOVERNO DE JANGO E O GOLPE DE 1964}

O governo de João Goulart carregou a pecha de ser o herdeiro das ações varguistas, durante a última administração de Getúlio, ao longo da Terceira República, Jango foi ministro do trabalho. Após cinco anos de arrocho salarial promovido pelo presidente Eurico Gaspar Dutra, Vargas decide implementar um aumento do salário mínimo de I0o\%, justamente quando Goulart exercia seu ministério. Esta foi uma, diante de várias medidas trabalhistas, que marcaram o legado getulista e que incomodaram os opositores de seu governo. ${ }^{3}$

\footnotetext{
${ }^{3}$ COSTA, Célia. A crise política se aprofunda > João Goulart, o aumento do salário mínimo e o Memorial dos Coronéis. Rio de Janeiro: FGV/CPDOC - E ele voltou... O Brasil no segundo governo Vargas. 2020. Disponível em: <https://cpdoc.fgv.br/producao/dossies/AEraVargas2/artigos/CrisePolitica/JoaoGoulart> . 05/02/2021.
} 
Após esta experiência ministerial durante a era varguista, Jango deveria assumir a Presidência da República, quando Jânio Quadros renuncia acreditando ter apoio popular o suficiente para receber os "louros" de uma vitória futura, em um ensaio bem parecido ao de Getúlio quando escreveu sua carta-testamento em 1954. Portanto, em 196I, João Goulart, por ter sido eleito vice-presidente nas ultimas eleições, teria que ser o representante do executivo.

\begin{abstract}
No dia 25 de agosto de 1961, Jânio Quadros resignava sem ao menos completar sete meses na Presidência da República. Na carta-renúncia autêntica paródia e pastiche da carta-testamento de Getúlio Vargas, como observaram diversos autores -, Quadros não formulou uma única razão convincente para explicar e justificar o seu teatral gesto. Se, naquele momento, a denúncia do golpe janista soava como uma mera especulação, hoje restam poucas dúvidas a esse respeito. A rigor, a renúncia constituíase no primeiro ato de uma trama golpista. Julgava o demissionário que os ministros militares não apenas impediram a posse de João Goulart, como também procurariam impor, juntamente com o massivo e sonoro "clamor popular", o retorno do "grande líder". Na sua fantasia, Quadros voltaria, pois, nos "braços do povo". (TOLEDO, 1988, p.4)
\end{abstract}

Os conflitos políticos que se sucederam no momento em que Jango tomaria posse, levaram o país a uma modalidade administrativa que era uma novidade durante o período republicano, seria o parlamentarismo, contudo, antes disso, viria o veto à posse de Goulart, taxado de forma sorrateira pelos setores conservadores como um representante das esquerdas que impediriam o "avanço" e o "progresso" do Brasil.

No dia 28 de agosto, através do presidente-interino, os três ministros militares buscaram impor ao Congresso a aprovação de uma breve nota onde - sem qualquer justificativa - era vetada a posse de Goulart. Por uma expressiva maioria, os congressistas manifestaram-se contra aquela arbitrária e ilegal exigência. No dia 30, os ministros militares voltariam à carga. Através de um manifesto à nação, agora se designavam a explicitar as razões do veto a João Goulart. A certa altura, afirmava o documento: "Na Presidência da República, em regime que atribui ampla autoridade e poder pessoal ao chefe do governo, o sr. João Goulart constituir-se-á, sem dúvida alguma, no mais evidente incentivo a todos aqueles que desejam ver o País mergulhado no caos, na anarquia, na luta civil". Todas estas "previsões" eram feitas na base do passado político de Goulart. Na ótica dos militares e dos demais setores civis golpistas, Jango simbolizava tudo aquilo que havia de "negativo" na vida política brasileira: demagogo, subversivo e implacável inimigo da orem capitalista. Seria o "diabo" tão vermelho como o pintavam? (TOLEDO, 1988, p.6)

Todo esse caminho que impedia Goulart tomar posse, definitivamente, à

Presidência da República levou a construção parlamentarista, solução viável naquele 
momento para manter-se os direitos políticos de exercício de Jango, através da campanha pela Legalidade encabeçada pelo seu cunhado Leonel Brizola, João Goulart teve respaldo do legislativo.

A renúncia de Jânio Quadros à Presidência da República, em 25 de agosto de 196r, jogou o país em gravíssima crise política e militar. O vicepresidente era João Goulart, líder do Partido Trabalhista Brasileiro (PTB), herdeiro político de Getúlio Vargas e homem aberto ao diálogo com o movimento sindical $e$ as esquerdas. Os três ministros militares, insatisfeitos com sua posse na Presidência da República, tramaram um golpe de baixo custo contra as instituições democráticas: coagiram o Congresso Nacional a decretar o impeachment de Jango, como também era conhecido o vice-presidente. No entanto, os partidos políticos, incluindo a União Democrática Nacional (UDN), recusaram a intimidação militar. As principais lideranças do Congresso defenderam a posse de João Goulart, como determinava a Constituição. O governador do Rio Grande do Sul, Leonel Brizola, liderou a resistência democrática. O país foi mobilizado por uma cadeia de rádios. A sociedade respondeu com entusiasmo no sentido de preservar a Constituição: sindicatos de trabalhadores, a União Nacional dos Estudantes (UNE), a Ordem dos Advogados do Brasil (OAB) e a Conferência Nacional dos Bispos do Brasil (CNBB) defenderam a ordem legal. A imprensa apoiou o cumprimento da Constituição e somente poucos jornais, como $O$ Estado de S. Paulo, a Tribuna da Imprensa e O Globo, apoiaram o golpe dos ministros militares. A Campanha da Legalidade, como ficou conhecido o movimento pela defesa da democracia, fortaleceu o Congresso Nacional diante dos ministros militares, enquanto setores majoritários das Forças Armadas não estavam dispostos a golpear as instituições. Das esquerdas aos partidos conservadores, formou-se a ampla coalizão pela manutenção da legalidade democrática. Para superar o impasse, os partidos políticos chegaram a um acordo: Goulart assumiria a Presidência da República, mas sob regime parlamentarista. A solução de compromisso com o parlamentarismo garantiu a continuidade do processo democrático, mas restringiu seus poderes políticos. (FERREIRA, 2019, p. 404-405)

O término desta estrutura parlamentarista só veio a acontecer em 1963 com o plebiscito. A vitória de Jango o colocaria, finalmente, como Presidente do Brasil, detentor do Poder Executivo sem a subordinação ao Poder Legislativo. Além disso, este triunfo eleitoral daria forte apoio popular ao governo de Jango, mesmo diante de diversas crises políticas e econômicas. Para Ferreira (2019, p. 418) “[..] A vitória de Goulart foi avassaladora: dos in milhões e quinhentos mil eleitores, 9 milhões e quinhentos mil, ou cinco em cada seis, aprovaram o retorno ao regime presidencialista".

Estava agora o caminho aberto para as Reformas de Base do governo de João Goulart, elas atingiriam diversos setores da economia, da política, dentre outros. 
Sempre foi o alicerce de seu governo este projeto reformista, contudo, vale para Toledo (1988, p. 26) “[...] Reconhece-se, no entanto, que a bandeira das Reformas passou a ser empunhada pelo governo, de forma mais enérgica, no período presidencialista, apenas a partir do instante em que se começou a perceber o malogro do Plano Trienal”.

O Brasil ficava assim fragmentado em dois projetos distintos de país, de um lado os conservadores que uniam os militares de altas patentes das Forças Armadas, a elite cristã que esteve simbolizada como uma metonímia deste grupo na Marcha da Família com Deus pela Liberdade, a União Democrática Nacional (UDN) - liderada por Carlos Lacerda e os meios de comunicação e do outro lado, os setores progressistas da sociedade que apoiavam a legalidade do governo de João Goulart, incluíam-se, principalmente, os grupos de artistas e intelectuais, o Partido Comunista Brasileiro (PCB), União Nacional dos Estudantes e setores sindicais como a Central Geral dos Trabalhadores (CGT). Como marco maior da visibilidade do apoio desta importante parte da sociedade, Jango fez o seu pronunciamento no que ficou conhecido como o Comício da Central do Brasil, sendo uma tentativa, também, de conciliação com as Forças Armadas, o que de fato não aconteceu devido ao golpe em 3i de março e io de abril de 1964 .

\footnotetext{
Eram 20:46 horas quando João Goulart tomou a palavra, falando de improviso. Ele atacou setores da elite que, em nome da democracia, procuravam perpetuar privilégios intoleráveis, criticou a indústria do anticomunismo, ressaltou a necessidade de revisar a Constituição e lamentou a cegueira de parcela da sociedade de instrução superior que continuam insensíveis à realidade nacional. No entanto, o governo, ao lado do povo, operários, camponeses, militares, estudantes, intelectuais e empresários patriotas, e com o seu apoio, prosseguirá na luta pela emancipação econômica e social do país. [...] Após agradecer aos trabalhadores pela presença, afirmou que nenhuma força seria capaz de impedir que o governo assegurasse a liberdade ao povo, contando, para isso, com a compreensão e patriotismo das Forças Armadas. (FERREIRA, 2019, p. 439-440)
}

Não atingida esta conciliação, órgãos de fomento das propostas golpistas, tais como o Instituto de Pesquisas e Estudos Sociais (IPES) e o Instituto Brasileiro de Ação Democrática (IBAD), deram as diretrizes que auxiliaram no Golpe de 1964, "barrar" o populismo calcado no trabalhismo e estadismo forte, interromper as lutas 
pela libertação nacional e retirar a participação popular da vida cotidiana dos debates do Estado. Era um fim de um período de efervescência política, mas, não menos importante, de grande ebulição de ações no campo das artes e da cultura como veremos no terceiro capítulo deste trabalho.

\begin{abstract}
Os associados e colaboradores do IPES moldaram o sistema financeiro e controlaram os ministérios e os principais órgãos da administração pública, permanecendo em cargos privilegiados durante o governo de Castello Branco, exercendo sua mediação de poder. Com um programa de governo que emergia da direita do espectro político e social, os ativistas do IPES impuseram uma modernização da estrutura sócio-econômica e uma reformulação do aparelho do Estado que beneficiou, de maneira ampla, as classes empresariais e os setores médios da sociedade, em detrimento da massa. O golpe de abril de 1964 desdobrou-se numa transformação do Estado: o programa do IPES trazia em seu bojo uma regeneração capitalista. (DREIFUSS, 198I, p. 455)
\end{abstract}

\title{
BREVE HISTÓRICO DO CPC DA UNE
}

O Centro Popular de Cultura - CPC da União Nacional dos Estudantes UNE foi arquitetado com o objetivo de desenvolvimento de uma cultura em busca da identidade nacional com forte ligação aos objetivos da esquerda brasileira. Para Napolitano (2020, p. 37) "O projeto político-cultural do 'CPC da UNE', tal como foi apresentado no manifesto da entidade, [...], foi herdeiro da forma pela qual o problema do espaço político e social do nacional-popular foi lido no Partido Comunista”. Contudo, não necessariamente a totalidade de seus membros era engajada na militância do Partido Comunista Brasileiro (PCB), o que não exclui o fato de que existiam militantes deste partido e, além disso, o grande cerne de congruência entre os realizadores do CPC era o desenvolvimento do nacionalismo sobre a perspectiva esquerdista.

[...] Não significa que todas as pessoas que participavam do CPC eram "comunistas de carteirinha", como se dizia, mas de alguma forma gravitavam em torno da cultura nacionalista de esquerda, da qual o PCB era um grande defensor. Eram jovens, quase sempre estudantes e artistas os que se articulavam, a partir de 196r, em torno da UNE, e passaram a defender que a entidade tivesse uma política cultural mais atuante. $\mathrm{O}$ ponto de comum entre eles era a defesa do nacional-popular, expressão que designava, ao mesmo tempo, uma cultura política e uma política cultural das esquerdas, cujo sentido poderia ser traduzido na busca da expressão simbólica da nacionalidade, que não deveria ser reduzida ao regional folclorizado (que representava uma parte da nação), nem com os padrões universais da cultura humanista - como na cultura das elites burguesas, por exemplo. (NAPOLITANO, 2020, p. 37) 
Como o país vivia seu período de fortalecimento das estruturas políticas nacionalistas, tendo em vista os governos de Getúlio Vargas (nacionalização da economia) e João Goulart com as Reformas de Base, o Plano Trienal e a Lei de Remessa de Lucros, as propostas sociais influenciavam na luta dos estudantes e intelectuais que idealizavam uma arte menos elitizada e mais voltada ao popular. A ideia central era construir uma arte que entrasse no ceio da sociedade como um manifesto do nacionalismo, seria um desgarrar das interferências do imperialismo capitalista, deixando de lado preocupações com estéticas mais rebuscadas.

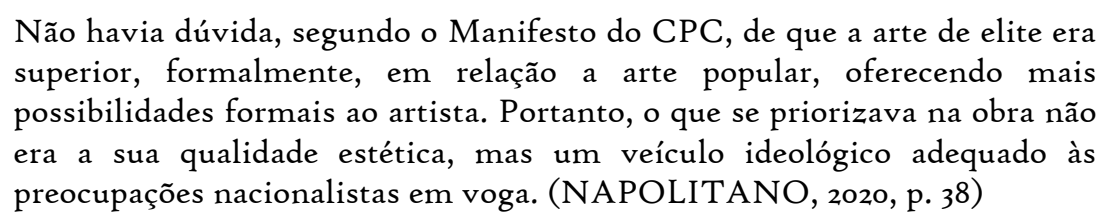

Como o movimento do CPC era artístico e intelectual suas atividades abrangiam o teatro, o cinema, a música, a literatura e as atividades em geral. Tendo em vista alcançar mais pessoas no território nacional foi desenvolvida a UNEVolante, onde o CPC poderia difundir mais as suas manifestações culturais, sendo criado o Departamento de Relações, este foi o período de forte apego ao projeto de identidade nacional, entre 196 I e 1962. Vale destacar aqui neste trabalho a contribuição do cinema ao CPC, onde Berlinck (1984, p. 27) destaca que no “Departamento de Cinema reuniu, entre outros, Leon Hirsman, Carlos Diegues, Marcos Farias, Miguel Borges, Teresa Aragão”.

No teatro o grande destaque dava-se pela construção do Teatro de Arena que se manteve como arma ideológica de resistência após o golpe de 1964, tal como afirma Napolitano (2020, p. 53) "Nesse sentido, Arena...também funcionou como um movimento de repensar a perspectiva política que informava os seguimentos nacionalistas, após o golpe de 1964”.

As peças Eles não usam black-tie de Gianfrancesco Guarnieri, A vez da recusa, de Carlos Estevam, Auto do tutú tá no fim e Auto dos Cassetetes, ambas de direção de João das Neves, Os Azedo mais os Benevides de Oduvaldo Viana Filho, entre outras, estão enraizadas nas temáticas do operário, do estudante militante, do homem 
simples em meio aos entraves da vida política cotidiana, as obras teatrais não objetivavam apresentações em grandes "palácios" teatrais do país, mas as praças públicas, as universidades, os locais onde os populares estivessem.

O teatro de agitação baseava-se num fato político qualquer como, por exemplo, uma Conferência dos Estados Americanos ou o aumento de preços de algum gênero alimentício que causasse problemas maiores. Sobre o fato uma peça era imediatamente feita e levada prá rua, em qualquer lugar: em praça pública, em cima de um caminhão, em cima de caixas d'água de favelas. (BERLINCK, 1984, p. 29)

$\mathrm{Na}$ música os integrantes do CPC tinham o grande desafio de como se relacionar com a Bossa Nova diante das questões do nacionalismo, via-se uma forte tentativa de trazer a construção elitista musical para uma formação de conscientização social de todas as classes, ingressando os ideias do Partido Comunista Brasileiro (PCB) este planejamento dos artistas marcava a trajetória musical do CPC durante o governo de João Goulart.

Carlos Lyra, Sérgio Ricardo, Nelson Lins e Barros, Vinícius de Moraes e outros, destacavam a música popular como meio para problematizar a consciência dos brasileiros sobre sua própria nação e elevar o nível musical popular. $\mathrm{Na}$ perspectiva deles, a ideologia nacionalista era um projeto de setor da elite que, a médio prazo, poderia beneficiar a sociedade como um todo e a "subida ao morro" (expressão que sintetizava o contato com as classes populares) visava muito mais ampliar as possibilidades de expressão e comunicação da música popular renovada do que imitar a música das classes populares. Essa perspectiva foi mais determinante até 1964, quando a conjuntura mudou e levou alguns artistas de esquerda a se aproximar das matrizes mais populares da cultura brasileira (como as praticadas nas comunidades do morro e do sertão) como uma reação ideológica ao fracasso da "frente única" (a política de aliança de classes sociais e tendências políticas diferentes em nome da defesa da nação) idealizada pelo PCB. (NAPOLITANO, 2020, p. 4I)

O principal Long Play (LP) que representa este contexto do CPC é O povo canta, obra que argumenta muito bem a relação íntima do povo diante de seus problemas sociais, a necessidade de uma linguagem atingisse as massas, mas que ao mesmo tempo proporcionava a criticidade social.

As composições reunidas neste disco representam uma experiência nova na música popular. Nelas, os elementos autênticos da expressão coletiva são utilizados para, através deles, chegar a uma forma de comunicação eficaz com o povo, esclarecendo-o, ao mesmo tempo a respeito de problemas atuais que o atingem diretamente. $O$ povo canta desloca o sentido comum da música popular, dos problemas puramente individuais para um âmbito geral: o compositor se faz o intérprete esclarecido dos 
sentidos populares, induzindo-o a perceber as causas de muitas das dificuldades com que se debate. (BERLINCK, i984, p. 35)

Lógico que as práticas do CPC enfrentaram dificuldades de distanciamentos entre classes, característico do Brasil do período da República Populista, mas é inegável a grande contribuição destes jovens intelectuais e estudantes no fomento de uma arte engajada, no cinema o desenrolar dos cinemanovistas estará intrínseco neste contexto, o que veremos no próximo capítulo.

\section{O CINEMA NOVO DURANTE O GOVERNO DE JOÃO GOULART}

O que chamamos de Cinema Novo foi um movimento cinematográfico que buscava a formação de uma linguagem através da construção da identidade nacional sofrendo diversas influências artísticas que não viriam para serem copiadas, mas, assim como na Semana de Arte Moderna de 1922, estariam sendo referências para uma cultura popular.

Inspirados pelo despojamento do neorrealismo italiano, pelas inovações da Nouvelle Vague francesa e, mais proximamente, pelo cinema independente brasileiro dos anos 1950, os cinemanovistas não queriam - nem poderiam fazer filmes nos padrões do tradicional cinema narrativo de "qualidade", americano em sua maioria, que o público brasileiro estava acostumado a ver. O cinema que pretendiam fazer deveria ser "novo" no conteúdo e na forma, pois, seus novos temas exigiriam também um novo modo de filmar. (CARVALHO, 2012, p. 290)

O próprio início das realizações cinematográficas ligadas ao movimento do Cinema Novo encontra convergência com o CPC da UNE, para Napolitano (2020, p. 45) "a rigor, o movimento do Cinema Novo começou por volta de 1960, com os primeiros filmes de Glauber Rocha, Ruy Guerra e outros jovens cineastas engajados e durou até 1967." Neste período, dentro do CPC destaca-se a formação das obras fílmica Cinco vezes favela, entre os anos de 196r e 1962, fomentadas pelos cineastas que contribuíram ao cinemanovismo no qual cada um dirigiu um curta-metragem com temáticas sociais e populares, são estes: Um favelado, de Marcos Farias, Escola de Samba Alegria de Viver, de Carlos Diégues, Zé da Cachorra, de Miguel Borges, Couro de Gato, de Joaquim Pedro de Andrade, e Pedreira de São Diogo, de Leon Hirszman. Segundo Jean-Claude Bernardet (2007, p. 4I) "tal radicalismo, característico da época, ajudou imensamente a evolução das idéias cinematográficas do Brasil. Esse também foi o principal papel de Cinco Vezes Favela". 
A grande "tacada" do CPC era proporcionar no público um engajamento diante de sua situação social. O Brasil republicano da década de 1960 vivia sua experiência de vinda de empresas internacionais, de heranças varguistas na economia, de um crescimento no setor industrial, paralelo a isto, a população visualizava as disparidades financeiras entre as classes sociais, os processos de afavelamentos, a luta das Ligas Camponesas, o crescimento da Central Geral dos Trabalhadores, e com isto os cineastas do CPC estimulavam esta criticidade em seus filmes.

O CPC pretendia, por meio de peças teatrais, filmes ou outras atividades, levar a um público popular informações sobre sua condição social, salientando que as más condições de vida decorrem de uma estrutura social dominada pela burguesia. Tarefa de conscientização: deve-se ir além da descrição e da análise da realidade, a fim de levar o público a atuar; a situação não mudará se ele não agir para transformá-la e só ele pode ser o motor dessa transformação. Trata-se de politizar o público. Essa militância é a finalidade de Cinco vezes favela: o ladrão da favela não é ladrão porque não queria trabalhar, mas porque não encontra serviço e precisa comer; é a sociedade que faz o ladrão (Um favelado). Se o favelado não tem onde dormir, é porque até os barracos da favela pertencem a um rico proprietário que dispõe de seus bens a seu bel-prazer (Zé da Cachorra). Se o favelado preocupa-se mais em organizar as festas da escola de samba do que participar da vida sindical para alterar a sociedade, tudo ficará na mesma (Escola de Samba Alegria de Viver). (BERNARDET, 2007, p. 4I-42)

Ainda na passagem de Jango pela presidência outras obras que valem serem lembradas pela contribuição da linguagem lírica dentro do Cinema Novo os filmes: Porto das Caixas, de Paulo César Saraceni e A falecida, de Leon Hirszman, o que prova a complexidade de definições das obras cinemanovistas, para Ramos (2018, p. I2I) "Porto das Caixas, um pouco mais precoce, compõe esse quadro do Cinema Novo com inspiração literária”.

Estas duas obras trazem o olhar do feminismo iniciante para o cinema brasileiro, em uma época em que o papel da mulher na sociedade era extremamente compelido pelo algoz machista. Mais uma forte riqueza de produções que marca este período político do Brasil da Terceira República.

As protagonistas femininas de Porto das Caixas, O Padre e Moça e A falecida possuem, portanto, o traço lírico que se afirma pela negação do universo masculino e se afunda na feminilidade exasperada, melancólica, triste, e alucinada, voltada para si: seja na negação do desejo do padrasto por Mariana (e sua descoberta no homem que não pode tê-la sexualmente, 
o padre); seja no desejo de auto-aniquilação que tudo abarca em A falecida; seja na ação pérfida, mas libertadora e afirmativa do ego feminino pelo assassinato do marido em Porto das Caixas. (RAMOS, 2018, p. 123)

Esta marca de idealização de uma arte que precisa ser uma "pedra na vidraça" identifica definitivamente o contexto em que o Cinema Novo estava inserido, um período com forte pressão social, um país dividido entre uma elite conservadora que queria manter o status-quo e uma classe trabalhadora que necessitava inserir-se nos dilemas sociais, esta conjuntura fazia com que grandes obras de apelo ao público operário também fossem excluídas do mundo cinemanovista, eis o grande dilema deixado por esta geração de realizadores para o país pós-golpe de 1964 .

Curiosamente, o maior triunfo do cinema brasileiro, o filme $O$ pagador de promessas, não era aceito como parte do conjunto de obras do Cinema Novo e sua "estética da fome", pelos principais diretores do movimento. Alguns anos antes, esse filme dirigido por Anselmo Duarte, ganharia o prêmio máximo do Festival de Cannes de 1962. A comovente história do Zé do Burro, homem que quer entrar com uma cruz na Igreja para pagar uma promessa, mas é barrado na porta pelo padre, que não admitia aquela "blasfêmia", não pode ser enquadrada nos princípios da violência simbólica. Mais próximo de uma estética neorrealista e dentro dos padrões clássicos de narrativa cinematográfica linear, $\mathrm{O}$ pagador de promessas não buscava o choque, mas fazia com que o público, independentemente da classe social ou da formação cultural, sofresses junto com aquele homem simples, cuja única desgraça foi querer agradecer a Deus por ter salvado o seu jumento, peça fundamental no seu trabalho diário camponês. (NAPOLITANO, 2020, p.46)

\section{CONCLUSÃO}

O período da história do Brasil que vai desde o término do Estado Novo (1945) e as eleições presidenciais que levaram à presidência o General Eurico Gaspar Dutra (1946) até o golpe militar de 1964 é caracterizado pelas ações populistas e nacionalistas. Neste intervalo, além de Dutra, o país teve como representantes do Poder Executivo, Getúlio Vargas, Café Filho, Carlos Luz, Nereu Ramos, Juscelino Kubitschek, Jânio Quadro e João Goulart. E foi, justamente, durante o governo de Jango que tivemos uma maior mobilização das artes em prol do engajamento político.

Após a renúncia do presidente Jânio Quadros, Jango, teve diversas crises políticas que o impeliam de tomar, era o prenúncio do golpe de 1964. De 1961 até 1963, Goulart esteve diante do parlamentarismo e só depois de um plebiscito popular que definitivamente o presidencialismo esteve nas "mãos" do vice-presidente eleito em 1960. 
Assim como as Ligas Camponesas e os movimentos sindicais que se intensificavam cada vez mais nas lutas dos trabalhadores, estavam também, os estudantes, institucionalizados pela União Nacional dos Estudantes (UNE), porém, sua poderosa "arma" de combate político seria a arte como meio para a conscientização popular e construção de identidade nacional.

É imprescindível ressaltar que neste ponto o Centro Popular de Cultura (CPC) teve papel fundamental na difusão e fortalecimento do movimento do Cinema Novo, sendo o local de produções, exibições e principalmente, de se pensar sobre uma estética que atingisse o trabalhador, operário. Assim como majestosamente define Ortiz (1994, p.72) "da perspectiva da ação política, deriva de fato a questão dos intelectuais e da organização da cultura. Neste sentido, a problemática do CPC é vizinha àquela estudada por Grasmci nos Cadernos do Cárcere".

\section{REFERÊNCIAS}

AGUIAR, Carolina Amaral de; CARVAlHO, Danielle Crepaldi; MORETTIN, Eduardo; MONTEIRO, Lúcia Ramos; ADAMATTI, Margarida Maria. (org.). Cinema e História: circularidades, arquivos e experiência estética. Porto Alegre:

Sulina, 2017.

BARCELOS, Jalusa. CPC da UNE: uma história de paixão e consciência. Rio de Janeiro: Nova Fronteira, 1994.

BARROS, José D'assunção. Teoria da História: A Escola de Annales e a Nova História. Volume V. Petrópolis-RJ: Editora Vozes, 2012.

BERLINCK, Manoel T. O Centro Popular de Cultura da UNE. Campinas-SP: Papirus, 1984.

BERNARDET, Jean-Claude. Brasil em tempos de cinema: ensaio sobre o cinema brasieliro de 1958 a 1966. São Paulo: Companhia das Letras, 2007.

CARVAlHO, Maria do Socorro. Cinema Novo Brasileiro. In: MASCARELLO, Fernando. (org.). História do cinema mundial. $7^{\text {a }}$ edição. Campinas-SP: Papirus, 2012. p. 289-309.

COSTA, Célia. A crise política se aprofunda > João Goulart, o aumento do salário mínimo e o Memorial dos Coronéis. Rio de Janeiro: FGV/CPDOC - E ele voltou... $\mathrm{O}$ Brasil no segundo governo Vargas. 2020. Disponível em: 
<https://cpdoc.fgv.br/producao/dossies/AEraVargas2/artigos/CrisePolitica/JoaoG oular $>$. 05/02/2021.

DREIFUSS, René Armand. 1964: a conquista do Estado: ação política, poder e golpe de classe. $3^{\mathfrak{a}}$ edição. Petrópolis-RJ: Vozes, 1981.

FERREIRA, Jorge. O governo de João Goulart e o golpe civil-militar de 1964. In: FERREIRA, Jorge; DELGADO, Lucilia de Almeida Neves (org.). O Tempo do Regime Autoritário: ditadura militar e redemocratização: Quarta República (19641985). 9 $9^{\text {a }}$ edição. Rio de Janeiro: Civilização Brasileira, 2019. (O Brasil Republicano; 4). p. 403-468.

FERRO, Marc. Cinema e História. Rio de Janeiro-RJ: Paz e Terra, 1992.

FIGUERÔA, Alexandre. Cinema Novo: a onda do jovem cinema e sua recepção na França. Campinas-SP: Papirus, 2004.

LE GOFF, Jacques. História \& Memória. $7^{\text {a }}$ edição revista. Campinas-SP: Editora da Unicamp, 2013.

NAPOLITANO, Marcos. A história depois do papel. In: PINSKY, Carla Bassanezi (org.). Fontes Históricas. $3^{\underline{a}}$ edição. São Paulo: Contexto, 2019.

NAPOLITANO, Marcos. Cultura brasileira: utopia e massificação (I950 - 1980). $4^{\underline{a}}$ edição. São Paulo: Contexto, 2020.

ORTIZ, Renato. Cultura brasileira \& identidade nacional. $5^{\underline{a}}$ edição. São Paulo: Brasiliense, 2012.

RAMOS, Fernão Pessoa. Cinema Novo/Cinema Marginal, entre curtição e exasperação. In: _ _ SCHVARZMAN, Sheila. (org.). Nova história do cinema brasileiro. Vol. 2. São Paulo: Edições SESC, 2018. p. II6-20I

RIDENTI, Marcelo. O Fantasma da Revolução Brasileira. 2a edição revisada e ampliada. São Paulo: Editora UNESP, zoro.

ROLLEMBERG, Denise. Esquerdas revolucionárias e luta armada. In: FERREIRA, Jorge; DELGADO, Lucilia de Almeida Neves (org.). O Tempo do Regime Autoritário: ditadura militar e redemocratização: Quarta República (1964-1985). 9 ${ }^{\text {a }}$ edição. Rio de Janeiro: Civilização Brasileira, 2oı19. (O Brasil Republicano; 4). p. 4999 .

ROSENSTONE, Robert A. História nos filmes, os filmes na história. $2^{\text {a }}$ edição. Rio de Janeiro: Paz e Terra, 2015. 
SCHWARZ, Roberto. Cultura e Política. $3^{\text {a }}$ edição. São Paulo: Paz e Terra, 2009.

TOLEDO, C. N. 1964: golpismo e democracia: as falácias do revisionismo. Crítica Marxista, São Paulo, n. 19, p. 27-48, jul./dez. 2004.

XAVIER, Ismail. Sertão Mar: Glauber Rocha e a estética da fome. São Paulo: Duas Cidades; Editora 34, 2019.

XAVIER, Ismail. Alegorias do subdesenvolvimento: cinema novo, tropicalismo, cinema marginal. 2- reimpressão. São Paulo: Cosac Naify, 2012. 